\title{
Motivations for Using Information for Decision making in Virtual Communities: The Moderating Effects of Usage Behavior
}

\author{
Li-Ting Huang \\ Department of Information Management \\ Chang Gung University \\ lthuang@mail.cgu.edu.tw \\ Cheng-Kiang Farn \\ Department of Information Management \\ National Central University \\ ckfarn@mgt.ncu.edu.tw \\ Hann-Tarn Jeng \\ Institute of Accounting \\ National Central University \\ hjeng@ncu.edu.tw
}

\begin{abstract}
Virtual communities are increasingly being viewed as important shopping reference groups and are being used as a new medium for affecting sales. In virtual communities, individuals generally exchange product information with others. This information guides members on the best products and where to buy them. We investigated the motivation behind virtual community members' decision to use information when they inspire more individuals to join shopping reference groups and influence product sales. Most previous research on this subject has emphasized the influence of electronic word of mouth and the posters' opinions regarding product choice. We further developed this idea by examining the various perspectives that are part of virtual communities' nature vis-à-vis members' activities of posting, viewing, and accepting information. We also explored the comparative importance of motivating factors behind members' intentions to use information for purchase-related decision making in different groups from three perspectives: the social exchange theory, gratifications theory, and the information adoption model. We collected data through an online survey and by examining respondents' actual posting behaviors. We showed that the importance of economic, relational, and social factors differs among groups. "Information browsers" mostly browse through information, rarely post messages, and consider relational and social factors as the main contributors to using information for decision making. "Information consumers" expect effective information, rarely post messages, and consider relational factors as a major determinant. "Information providers," the primary posters, seldom accept others' opinions and consider economic and social factors important for the intention of using information for decision making.
\end{abstract}

Keywords: Decision Making, Usage Behavior, Emotional Trust, a Sense of Belonging, Virtual Communities. 


\section{Introduction}

Virtual communities gather individuals together to help them form relationships, share common goals and interests, and receive social support. Researchers, such as Hagel and Armstrong (1997), Pentina et al. (2008), and Zhou et al. (2007), pointed out that an additional function of virtual communities is economic exchange. On the one hand, Ridings et al. (2006) stated that virtual communities attract businesses as members' conversations and preferences are a source of considerable knowledge about a target market. On the other hand, individuals in virtual communities are motivated to conduct online shoppingassociated activities; this holds true particularly when strong social connections and trust are prevalent. Members of virtual communities discuss multiple dimensions of products or brands, such as price, effectiveness, reputation, usage experience, or potential problems (Hung and Li, 2007). Smith et al. (2005) indicated that online members' recommendations facilitate purchase-related decision making. Participants in virtual communities are expected to cultivate social networks longterm relationships, and shared values; hence, virtual communities can shape a subject norm to influence members' preferences (Pentina et al., 2008).

"Herd behavior," proposed by Banerjee (1992), describes a phenomenon in which individuals exhibit uniform behavior in social and economic situations, such as decision making. Information cascades, positive network effects, word-of-mouth effects, and conformity preferences constitute the major mechanisms of herd behavior (Bikhchandani et al., 1992). Individuals in virtual communities are engaged in various discussions and can be easily influenced to do what others are doing. Marketing professionals identify various ways to promote online shoppingassociated activities in virtual communities in accordance with herding, such as electronic word of mouth, interactive electronic storefronts, and shopping reference groups (Pentina et al., 2008). Much research has focused on the influence of electronic word of mouth on product choices in virtual communities; hardly any research has been conducted on shopping reference groups in virtual communities. The behavior of shopping reference groups includes not only propagating positive usage experience but also the influence of social networks. One of the prominent features of virtual communities is membership in a family-like group. Hence, we propose that electronic word of mouth and reference groups on shopping preferences simultaneously influence virtual communities and are effective only when others believe the information and are deeply involved in those communities.

Pentina et al. (2008) also emphasized the importance of how members valuate and make use of other members' opinions for purchase-related decision making. Most studies researching virtual community marketing observe postings and behaviors. This trend ignores the opinions of silent members, that is, "lurkers," who seldom post messages, but always view the messages in the virtual communities. Preece et al. (2004) pointed out that "posters" and "lurkers" have different attitudes toward virtual communities. Yet, it may be inappropriate to classify members into "posters" and "lurkers." There is very little research on the various types of behaviors in virtual communities.

Accordingly, the purpose of this exploratory study is to answer two questions: the first pertains to the types of behaviors that exist in a virtual community vis-à-vis posting, viewing, and using information. The second relates to the factors that influence members' use of others' opinions with regard to purchaserelated decision making. We expect this study to analyze members' behavior, perceptions, and intentions with regard to purchaserelated decision making from multiple perspectives and facilitate further understanding of marketing issues in virtual communities.

This study provides important insights for academic researchers and management practitioners by exploring the motivations behind members' adoption of information related to purchase-related decision making. This is done by viewing various members' usage be- 
havior in virtual communities. This study extends its consideration of members' opinions to include active and passive members, "divers," and members who post infrequently, based on the actual manner in which they treat information. The study also provides a guideline for understanding the comparative importance of motivations that members with different information usage behavior recognize. We begin with a literature review on virtual community involvement from the perspective of social psychology and the information adoption model. Further, we propose a research framework and hypotheses, describe our methodology, and provide the results of data analysis. Finally, we discuss the academic and managerial implications of our study as well as its limitations.

\section{Conceptual Background}

\section{Virtual communities as a medium for exchange of shopping information}

Virtual communities are becoming an important medium through which online shopping-associated activities are conducted (Hagel and Armstrong, 1997). Online shopping-associated activities include buying and searching for shopping information, such as product quality, price, and brand. Karakaya and Barnes (2010) further stated that consumer opinions in socially-based web sites influence consumer choice of brand or company when they are making purchases. Pentina et al. (2008) stated that the concept of virtual communities is broader than that of electronic word of mouth. Besides electronic word of mouth, virtual community participants are also involved in the formation of relationships, long-term social interaction, and values and norms exchange (Pentina, 2008). Because of social interaction, shopping reference groups are developed in virtual communities; these groups then influence individual evaluations, aspirations, or behavior (Pentina, 2008). Prior studies from the perspective of social psychology propose that an individual's motivation to join virtual communities can include the need for (1) social integration (a sense of belonging), (2) help in achieving goals by obtaining information, (3) realization of economic exchanges, (4) status enhancement (by impressing others), and (5) entertainment, as illustrated by the studies of Ridings and Gefen (2004) and Thibaut and Kelley (1959).

Ridings et al. (2006) indicated that the exchange of shopping information related to product evaluation, preferences, or opinions among reference group members is particularly true when virtual communities have strong social connections and trust among members. Moreover, Lessig and Park (1975) proposed that influence occurs when individuals perceive knowledge enhancement as an outcome and are capable of using the information for dealing with the environment. Whether shopping information is really used by members for purchase-related decision making is addressed later. When customers intend to use shopping information for decision making, they carefully examine members' explanations before they make the final decision (Komiak and Benbasat, 2006). Accordingly, we draw our research model from the perspectives of individual participants and the central role of information in virtual communities.

\section{Motivation of using information for purchase decision-making}

Researchers have proposed frameworks for investigating the motivations of individuals to join virtual communities. Balasubramanian and Mahajan (2001) considered three types of motivations by integrating economic and social activity within the context of a virtual community. These include focus-related utility (adding value to communities), consumption utility (obtaining value from communities), and approval utility (attaining selfenhancement or economic rewards). Based on this framework, Hennig-Thurau et al. (2004) further concluded that concern for other members, positive self-enhancement, social benefit, and economic incentives are important motivations for participating in virtual communities. Wang and Fesenmaier (2004a, 2004b) asserted four driving forces for joining virtual communities based on literatures and theories: functional needs, so- 
cial needs, psychological needs, and hedonic needs. Functional needs refer to specific activities and goals that members fulfill in virtual communities. Social needs indicate social support, relationship formation, and the trust of others. Psychological needs derive from self-identity, self-presentation, and selfefficacy theories, that is, a sense of belonging, presenting a self-image, and believing that s/he is capable of exerting control over her/his own functioning and/or external resources. Hedonic needs are related to enjoyment and entertainment. Chan et al. (2004) concluded that recognition, self-efficacy, selfesteem, and sense of community are the main drivers for participation in virtual communities.

Ridings et al. (2006) stressed an apt application of the social exchange theory (Thibaut and Kelley, 1959) regarding exchanges within virtual communities. The social exchange theory emphasizes that an individual's comparison of current intangible costs with future intangible benefits affects his/her intention to interact with others. However, trust is a central part of these exchanges and determines whether people choose to participate in a behavior because individuals have to rely on the reputation of others so as to ascertain that s/he can obtain future benefits.

Ridings et al. (2006) also attempted to predict the driving forces for joining virtual communities from the perspective of the gratifications theory proposed by Blumler and Katz (1974). They mentioned the need for social integration (belonging and affiliation), help in achieving goals (e.g., by obtaining information), realizing economic exchanges, status enhancement (by impressing and manipulating others), and entertainment as the major motivations for individuals to join virtual communities. These motivations are similar to Wang and Fesenmaier's (2004a, 2004b) framework.

Ridings et al. (2006) summed up three motivations for joining virtual communities based on the literature and various theories. These include information exchange, finding emotional support, and shopping support. Emotional support indicates a sense of belonging.
Shopping support indicates searching for referral information related to how and where to buy the best product. Riding et al. (2002, 2006) pointed out that strong social connections and trust are particularly significant factors for members of virtual communities to get involved in the information exchange process. Kim et al.'s (2011) study indicates customer emotional and social value is most important to their purchase intention in social networking communities.

Rabjohn et al. (2008) employed the information adoption model to investigate the adoption of online information. The information adoption model states that argument quality and source credibility are the major antecedents of information usefulness, and, in turn, influence information adoption (Sussman and Siegal, 2003). Information quality refers to the persuasive strength embedded in a message (Battacherjee and Sanford, 2006). The persuasive strength is the value of a message as perceived by the users (Cheung et al., 2008). The more the value of messages is perceived by the users, the greater their willingness to adopt the given information. Source credibility is related to the users' trust in the source of messages, that is, a virtual community. The central role of trust in relationship management as derived from the social exchange theory has also been considered.

\section{Research Model and Hypotheses}

\section{Economic considerations}

The social exchange theory indicates that individuals are willing to maintain relationships because of the expectation that to do so will be rewarding (Blau, 1968). Individuals voluntarily sacrifice self-benefits with the expectation of future gains. According to the information adoption model, information value and usefulness are predictors of information adoption (Cheung et al., 2008). Economic incentives are important factors for the exchange of information (Balasubramanian and Mahajan, 2001; Hennig-Thurau et al., 2004; Pentina et al., 2008; Ridings et al., 2006). "Expected benefits" have been considered 
the main determinants for information value in a variety of disciplines (Lope and Galletta, 2006). Individuals sacrifice their time to be involved in virtual communities because they expect to obtain more benefits from posting and viewing messages. Perceived benefits also stem from the evaluation of the usefulness of information for improving users' decision making (Yovits and Foulk, 1985). Once individuals think that they can benefit from participating in virtual communities, they will be more likely to use the shopping information found there for making purchase decisions. Hence, we propose:

H1: Perceived benefit from a virtual community is positively associated with intention to use information for decision making.

\section{Relational considerations}

In most researches, the definition of "virtual communities" is based on the concepts of communication and relationship building (Lee et al., 2003). Trust is one of the core concepts in relationship management and increases relationship strength (Morgan and Hunt, 1994). McKnight et al. (2002) categorized trust into three types based on the theory of reasoned action, including the disposition to trust, trusting belief, and trusting intention. The concept of trusting belief is consistent with that of cognitive trust, which focuses on the trustors' rational expectation of relying on the trustees (Komiak and Benbasat, 2004; McKnight et al., 2002). However, Kramer (1999) proposed that the rational choice perspective affords too small a role to emotional and social influences on trust decisions. Relational, emotional, and social influences are essential for sustaining virtual communities. Emotional trust refers to a secure and comfortable feeling toward the trustee (Komiak and Benbasat, 2004). Hence, emotional trust should be taken into account to explain how people actually make decisions.

From the perspective of the social exchange theory, trust is a key consideration for interpersonal interaction and participation because the individual must have a reasonable expectation of future benefits (Ridings et al., 2006). According to the theory of reasoned action, attitude is a major determinant of a person's intention to perform a given behavior (Fishbein and Ajzen, 1975). Individuals are more likely to get deeply involved in virtual communities and use information for decision making when they have a highly positive attitude, that is, emotional trust, toward these communities. Wang and Fesenmaier (2004a, 2004b) listed social needs as one of the driving forces for virtual communities. Social needs include socializing, forming relationships, and obtaining the trust of others. Hence, we propose:

H2: Emotional trust in a virtual community is positively associated with intention to use information for decision making.

\section{Social considerations}

From the perspective of the gratifications theory and social psychology, virtual communities provide individuals with social supports that shape a sense of belonging (Hampton and Wellman, 2001). Previous studies have indicated that a sense of belonging is the primary success factor for sustaining virtual communities (Hagerty et al., 1996 and Kim et al., 2004). Studies have concluded that emotional support and social integration are major motivations for joining virtual communities (Chan et al., 2004; Pentina et al., 2008; Ridings et al., 2006; Wang and Fesenmaier, 2004a, 2004b).

A sense of belonging is defined as, "the experience of personal involvement in a system or environment so that the individuals feel themselves to be an integral part of the system or environment" (Hagerty et al., 1992). Moreover, individuals with a higher sense of belonging are willing to dedicate more time and effort to virtual communities (Lin, 2007; Roberts, 1998). When individuals are highly involved in virtual communities, they will be more likely to believe that the information is worthy and helpful for them.

In addition, because of deep involvement, individuals are psychologically willing to rely on virtual communities and feel comfortable surfing them. Wang and Fesenmaier (2004a, 2004b) proposed that forming relationships is 
one of the driving forces for participating in virtual communities. Trust increases the strength of relationships (Morgan and Hunt, 1994). If individuals who perceive a sense of belonging want to maintain a strong relationship, they have to trust this virtual community. Hence, we propose:

H3: A sense of belonging to a virtual community is positively associated with the intention to use information for decision making.

H4: A sense of belonging to a virtual community is positively associated with emotional trust.

\section{The moderating effect of information activities}

Informational influence, proposed by Lessig and Park (1975), occurs in virtual communities. Ridings and Gefen (2004) indicated that one of the motivations to join virtual communities is the need for help in achieving goals. Individuals post, view, accept, and use shopping information in virtual communities. Although previous studies have generally focused on the behavior of "posters," the influence of "lurkers" in virtual communities cannot be disregarded. Lurkers are generally defined as individuals who visit a community, but do not post or post very infrequently (Ridings et al., 2006). Preece et al. (2004) proposed that lurkers and posters have different attitudes toward the community. Although both lurkers and posters want more social support and information on a given topic, posters think that they receive more benefit from the community and that their needs are better met (Preece et al., 2004). The results of the research of Ridings et al. (2006) show that lurkers differ from posters particularly in their willingness to provide information and exchange social support. Liao and Chou's (2012) study reveals that lurkers' attitudes toward knowledge adoption are more influenced by shared vision, and perceived usefulness, whereas posters are more influences by social trust and shared language. Therefore, the dimension of using information has to be given due consideration.
One of the main objectives of virtual communities is information exchange; most virtual community researches, however, overlook the value of information. We define "usage behavior" as members' feelings towards the value of information posted by others as well as members' behavior towards posting. Users' motivations for the intention to use information vary with the members' usage behavior. Active users in virtual communities will be different from passive users. For example, posters who think they receive more benefits from communities (Preece et al., 2004) will pay more attention to economic factors. Posters' messages induce a series of responses to these issues, leading them to think that they are guiding the discussion. The more responses a message induces, the more opportunities posters have to get helpful information. So, posting could have intrinsic and extrinsic gains for posters. However, users who have limited information themselves will tend to value others' information, as per the information cascade theory (Duan et al., 2009). Because users who seldom post may think they are onlookers and usually observe other members' usage behavior. Hence, users who seldom post may seek a sense of belonging and trust because they have to select credible sources to follow. Hence, we propose:

H5: The influence of the determinants regarding intention to use information for decision making is moderated by the types of members' usage behavior in a virtual community.

H5a: The association of perceived benefit and intention to use information for decision making varies with the types of members' usage behavior in a virtual community.

H5b: The association of a sense of belonging and intention to use information for decision making varies with the types of members' usage behavior in a virtual community.

H5c: The association of emotional trust and intention to use information for decision making varies with the types of 


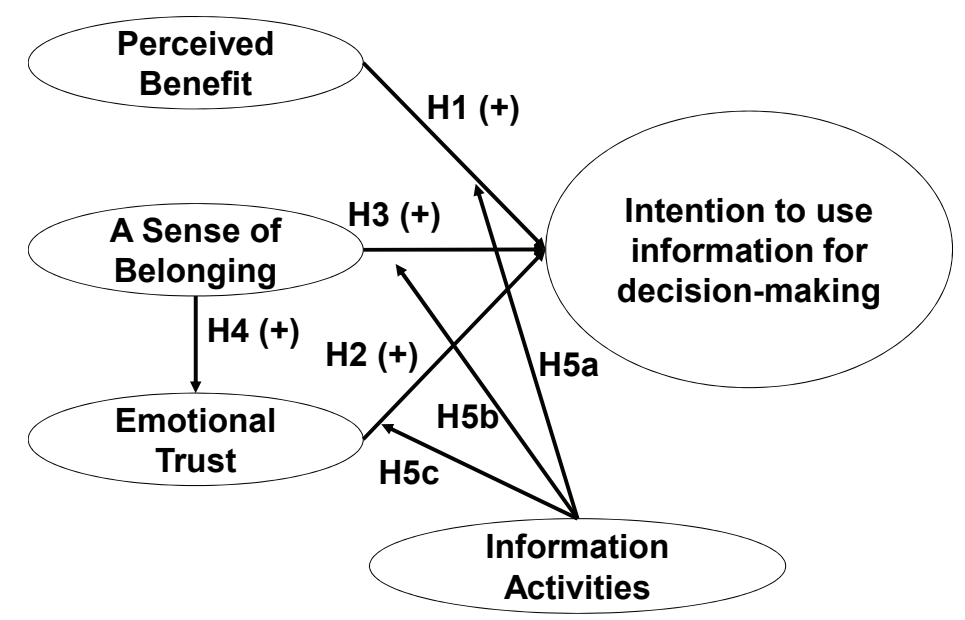

Figure 1 - Research Model

members' usage behavior in a virtual community.

The proposed research model is shown in Figure 1.

\section{Research Methodology \\ Operationalization and Instrument De- sign}

The instruments for the constructs have been adapted from literatures and revised to fit our research context, as shown in Table 1. They include, "intention to use information for decision making," "perceived benefit," "a sense of belonging," and "emotional trust." All items were anchored on 7-point Likert scales, ranging from strong disagreement to strong agreement. A short interview with several colleagues and experts and a pre-test were carried out to ensure the face and content validity of the compliant questionnaires.

"Usage behavior" included members' activities of posting, viewing, and valuating information in virtual communities and was measured on the basis of the member's posts and level of information use. Posting and viewing were represented by the number of members' posts collected from the targeted virtual community's historical records. Valuating information was represented by the level of in- formation use, including such rubrics as, "all information in virtual communities is viewed only as a reference," "information posted by a specific someone is adopted," "information posted by a specific group is adopted," and "all information in virtual communities is adopted." If information is valuable to members, members will think that the opinions presented in the virtual community are worth accepting.

\section{Data Collection}

A web-based questionnaire was administered to the members of a targeted virtual community for data. The first page described the objectives of this study and ensured confidentiality. This community was chosen because it is the most popular beauty virtual community in Taiwan. This community has formed several groups for discussing and introducing many kinds of beauty- and fashion-related products.

A message announcing this survey was posted for two weeks. Moreover, the virtual community manager provided us with the participants' demographics and their post numbers. The demographics included sex, age, income, occupation, and years of membership. These data are only for participant profiles and data analysis. In order to attract more participants 


\begin{tabular}{|c|c|c|}
\hline Construct & Definition & Measurement Items \\
\hline \multirow{3}{*}{$\begin{array}{l}\text { Intention to use } \\
\text { information for } \\
\text { decision making }\end{array}$} & \multirow{3}{*}{$\begin{array}{l}\text { The extent to which a member } \\
\text { is willing to depend on other } \\
\text { members' information for deci- } \\
\text { sion making (Komiak and Ben- } \\
\text { basat, 2006). }\end{array}$} & $\begin{array}{l}1 . \quad \text { I am willing to use the information in the virtual com- } \\
\text { munity as an aid to help my decision about which prod- } \\
\text { uct to buy. }\end{array}$ \\
\hline & & $\begin{array}{l}\text { 2. I am willing to use the information in the virtual com- } \\
\text { munity as a tool that suggests to me a number of prod- } \\
\text { ucts from which I can choose. }\end{array}$ \\
\hline & & $\begin{array}{l}\text { 3. I am willing to let the information in the virtual commu- } \\
\text { nity assist me in deciding which product to buy. }\end{array}$ \\
\hline \multirow{3}{*}{$\begin{array}{l}\text { Perceived } \\
\text { benefit }\end{array}$} & \multirow{3}{*}{$\begin{array}{l}\text { The extent to which partici- } \\
\text { pants perceive the content to } \\
\text { be associated with intrinsic } \\
\text { motivation (Lopes and Galletta, } \\
\text { 2006). }\end{array}$} & $\begin{array}{l}\text { 1. I can see several positive outcomes coming from the } \\
\text { use of this web site, such as money, time saved, en- } \\
\text { hanced decision making, completion of tasks, learning, } \\
\text { or entertainment. }\end{array}$ \\
\hline & & $\begin{array}{l}\text { 2. The use of this website would bring me a lot of re- } \\
\text { wards. }\end{array}$ \\
\hline & & $\begin{array}{ll}\text { 3. Overall, the expected benefits in using this website are } \\
\text { high. }\end{array}$ \\
\hline \multirow{4}{*}{$\begin{array}{l}\text { A sense of } \\
\text { belonging }\end{array}$} & \multirow{4}{*}{$\begin{array}{l}\text { The degree of the expectation } \\
\text { of personal involvement in a } \\
\text { system or environment, which } \\
\text { persons feel themselves to be } \\
\text { an integral part of the system } \\
\text { or environment (Hagerty et al., } \\
\text { 1992; Lin, 2007). }\end{array}$} & $\begin{array}{l}1 . \quad \text { I feel a strong sense of belonging to the virtual commu- } \\
\text { nity. }\end{array}$ \\
\hline & & I enjoy being a member of the virtual community. \\
\hline & & I am very committed to the virtual community. \\
\hline & & $\begin{array}{ll}4 . & \text { Overall, the virtual community has a high level of mo- } \\
\text { rale. }\end{array}$ \\
\hline \multirow{3}{*}{ Emotional trust } & \multirow{3}{*}{$\begin{array}{l}\text { The extent to which a member } \\
\text { feels secure and comfortable } \\
\text { about relying on a virtual } \\
\text { community (Komiak and Ben- } \\
\text { basat, 2006). }\end{array}$} & $\begin{array}{l}\text { 1. I feel secure about relying on the virtual community for } \\
\text { my decision. }\end{array}$ \\
\hline & & $\begin{array}{l}\text { 2. I feel comfortable about relying on the virtual communi- } \\
\text { ty for my decision. }\end{array}$ \\
\hline & & $\begin{array}{l}\text { 3. I feel content about relying on the virtual community for } \\
\text { my decision. }\end{array}$ \\
\hline
\end{tabular}

to this survey, the community provided trial samples of cosmetics as incentives. The respondents were self-selected for this study via posted messages.

During this two-week period, 355 questionnaires were completed. Of these, 309 were deemed usable. Up to $90 \%$ of our respondents were females as the targeted community focused on discussions about cosmetics. Approximately $67 \%$ of the respondents have been members of this community for 1 4 years. Only $11 \%$ have been members for $<1$ year. Since most respondents were experienced Internet users and discussion group participants, they were suitable for our study.

\section{Data Analysis and Results}

\section{Measurement Model}

Our measurement model employed confirmatory factor analysis using LISREL 8.50. The loading factors of all indicators were above the acceptable level of 0.5 and were significant $(p \leq 0.01)$. The statistics of fit indices were acceptable when compared with the desired levels suggested by Bentler (1980), as presented in Table 2. They reveal the acceptance of construct validity. Reliability and convergent validity were acceptable on comparison with the threshold values suggested by Bagozzi (1980), that, 0.7 and 0.5 respectively, as shown in Table 3. Discriminant validity was acceptable based on the rule that the correlations between any two distinct constructs are lower than the square root of the average variance extracted of those constructs (Fornell and Larcker, 1981), as shown in Table 4.

\section{Hypotheses Testing}

The structure model was analyzed using LISREL 8.50. Hypothesis testing was conducted in two steps. First, the main effect was examined $(\mathrm{H} 1 \sim \mathrm{H} 4)$. Second, the moderating 


\begin{tabular}{|c|c|c|c|c|c|c|c|c|}
\hline Table 2 - Model Fit Indices for the Measurement Model \\
\hline & $\chi^{2}$ & d.f. & $\chi^{2} /$ d.f. & $\begin{array}{c}\text { Standardized } \\
\text { RMR }\end{array}$ & RMSEA & NFI & CFI & GFI \\
\hline Model & 165.80 & 59 & 2.81 & 0.051 & 0.077 & 0.97 & 0.98 & 0.92 \\
\hline $\begin{array}{c}\text { Desired } \\
\text { levels }\end{array}$ & Not significant & - & $<5.0$ & $.05 \sim .08$ & $.05 \sim .08$ & $>.90$ & $>.90$ & $>.80$ \\
\hline
\end{tabular}

\begin{tabular}{|c|c|c|c|c|}
\hline Construct & Mean & SD & $\begin{array}{l}\text { Composite } \\
\text { Reliability }\end{array}$ & $\begin{array}{c}\text { Average Variance } \\
\text { Extracted }\end{array}$ \\
\hline Perceived benefit & 5.80 & 1.02 & 0.95 & 0.86 \\
\hline A sense of belonging & 5.85 & 0.84 & 0.92 & 0.75 \\
\hline Emotional trust & 5.95 & 0.80 & 0.99 & 0.97 \\
\hline Intention to use information for decision making & 5.33 & 1.10 & 0.97 & 0.92 \\
\hline
\end{tabular}

\begin{tabular}{|c|c|c|c|c|}
\hline Table 4 - Discriminant Validity & $\begin{array}{c}\text { Perceived } \\
\text { benefit }\end{array}$ & $\begin{array}{c}\text { A sense of } \\
\text { belonging }\end{array}$ & Emotional trust & $\begin{array}{c}\text { Intention to use } \\
\text { information for } \\
\text { decision-making }\end{array}$ \\
\hline Perceived benefit & $\mathbf{0 . 9 3}$ & - & - & - \\
\hline A sense of belonging & 0.69 & $\mathbf{0 . 8 7}$ & - & - \\
\hline Emotional trust & 0.45 & 0.65 & $\mathbf{0 . 9 9}$ & - \\
\hline $\begin{array}{c}\text { Intention to use information } \\
\text { for decision making }\end{array}$ & 0.57 & 0.74 & 0.60 & $\mathbf{0 . 9 6}$ \\
\hline Note: Diagonal represents the square root of the AVE of each construct \\
\hline
\end{tabular}

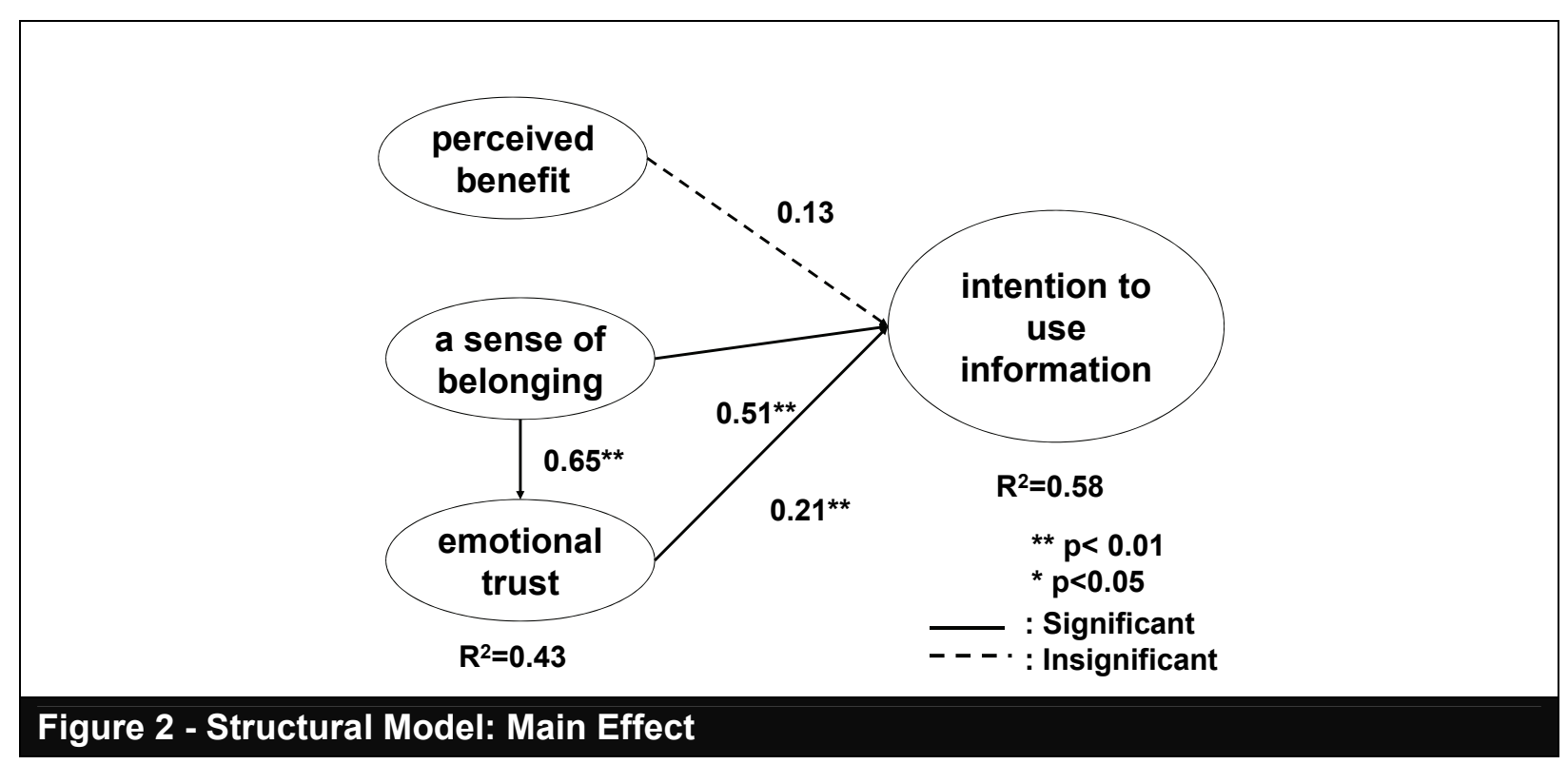


effect $(\mathrm{H} 5)$ was examined by multigroup structural equation modeling analysis. The samples were classified by cluster analysis.

The result of the main effect is presented in Figure 2. The statistics of fit indices were acceptable when compared with the desired levels suggested by Bentler (1980), as presented in Table 5 . Thus, the model fit the observed data well. Only the association of perceived benefit with the intention to use information for decision making was insignificant $(\mathrm{H} 1 ; \mathrm{t}=1.75)$. All other associations $(\mathrm{H} 2 \sim \mathrm{H} 4)$ were significant, and the directions were consistent with our predictions. The explained variance of the intention to use information for decision making and emotional trust was $58 \%$ and $43 \%$, respectively. The results thus revealed that a sense of belonging and emotional trust are important antecedents of the intention to use information for decision making. Moreover, a sense of belonging mediated by emotional trust also indirectly influences the intention to use information for decision making. When members rely emotionally on the virtual community and consider themselves to be an integral part of it, they are more willing to treat information as an important reference for purchase decisions.

The moderating effect of the types of usage behavior (H5) was evaluated in two steps. In the first step, the two-stage cluster analysis was performed based on the log of the number of posts and the level of information use in order to identify the possible groups. In the two-stage cluster analysis, hierarchy clustering by Ward's Method and measurement of the Squared Euclidean Distance was performed first, followed by K-Mean cluster analysis. The profiles of the final clusters are shown in Table 6.
The first cluster had 135 members. Members in the first group seldom posted information and viewed others' opinions only as an information resource. We named this cluster the "information browser." The second cluster consisted of 81 members. These members also seldom posted information; however, they believed to a greater extent in others' opinions. We named this cluster the "information consumer." The third cluster consisted of 93 members. These members always posted information on the virtual community, but referred to others' opinions only as one of the sources of information. We named this cluster the "information provider." According to our results, members who seldom posted information had two positions related to the worthiness of information: first, where they almost totally believed in others' opinions and second, where they treated the information from others' opinions simply as a reference.

LISREL 8.50 was used to examine the moderating effect of usage behavior by comparing the differences in the path coefficients among the three clusters. The fit indices of three model estimations were acceptable and revealed that these models fit the observed data well, as shown in Table 7. Figure 3 shows the result of the structural model estimation of three groups. The upper diagram is for the "information browser" group. The middle diagram is for the "information consumer" group. The bottom diagram is for the "information provider" group.

The association of perceived benefit with the intention to use information for decision making is insignificant. Members of this group generally have little confidence in the information from a virtual community and pay little attention to economic factors.

\begin{tabular}{|c|c|c|c|c|c|c|c|c|}
\hline \multicolumn{2}{|c|}{ Table 5 - Model Fit Indices for the Structural Model: Main Effect } \\
\hline & $\chi^{2}$ & d.f. & $\chi^{2} /$ d.f. & $\begin{array}{c}\text { Standardized } \\
\text { RMR }\end{array}$ & RMSEA & NFI & CFI & GFI \\
\hline Model & 143.81 & 58 & 2.48 & 0.049 & 0.069 & 0.98 & 0.99 & 0.93 \\
\hline $\begin{array}{c}\text { Desired } \\
\text { levels }\end{array}$ & $\begin{array}{c}\text { Not } \\
\text { significant }\end{array}$ & - & $<5.0$ & $.05 \sim .08$ & $.05 \sim .08$ & $>.90$ & $>.90$ & $>.80$ \\
\hline
\end{tabular}




\begin{tabular}{|c|c|c|c|c|c|c|}
\hline & \multicolumn{2}{|c|}{$\begin{array}{c}\text { Cluster } 1 \text { ( } n=135 \text { ) } \\
\text { (Information browser) }\end{array}$} & \multicolumn{2}{|c|}{$\begin{array}{c}\text { Cluster } 2(n=81) \\
\text { (information consumer) }\end{array}$} & \multicolumn{2}{|c|}{$\begin{array}{c}\text { Cluster } 3(\mathrm{n}=93) \\
\text { (Information provider) }\end{array}$} \\
\hline \multirow{7}{*}{$\begin{array}{c}\text { Number of } \\
\text { posts }\end{array}$} & 0 & $25.2 \%$ & 0 & $30.9 \%$ & $\geq 50$ & $0 \%$ \\
\hline & $1 \sim 5$ & $34.8 \%$ & $1 \sim 10$ & $30.9 \%$ & $51 \sim 100$ & $9.6 \%$ \\
\hline & $6 \sim 10$ & $17.8 \%$ & $11 \sim 20$ & $11.1 \%$ & $101 \sim 200$ & $19.3 \%$ \\
\hline & $11 \sim 38$ & $22.2 \%$ & $21 \sim 100$ & $18.5 \%$ & $201 \sim 400$ & $19.3 \%$ \\
\hline & $\geq 39$ & $0 \%$ & $101 \sim 1000$ & $6.2 \%$ & $401 \sim 600$ & $11.9 \%$ \\
\hline & & & $1001 \sim 3421$ & $2.4 \%$ & $601 \sim 1000$ & $11.9 \%$ \\
\hline & & & $\geq 3422$ & $0 \%$ & $1000 \sim 18030$ & $28.0 \%$ \\
\hline \multirow{4}{*}{$\begin{array}{c}\text { Levels of } \\
\text { information } \\
\text { use }\end{array}$} & $\begin{array}{l}\text { all information } \\
\text { from virtual com- } \\
\text { munities is used } \\
\text { only as a refer- } \\
\text { ence } \\
\end{array}$ & $87.4 \%$ & $\begin{array}{l}\text { all information } \\
\text { from virtual com- } \\
\text { munities is used } \\
\text { only as a refer- } \\
\text { ence }\end{array}$ & $0 \%$ & $\begin{array}{l}\text { all information } \\
\text { from virtual com- } \\
\text { munities is used } \\
\text { only as a refer- } \\
\text { ence }\end{array}$ & $82.8 \%$ \\
\hline & $\begin{array}{l}\text { information post- } \\
\text { ed by a specific } \\
\text { person is adopted }\end{array}$ & $12.6 \%$ & $\begin{array}{l}\text { information post- } \\
\text { ed by a specific } \\
\text { person is adopted }\end{array}$ & $0 \%$ & $\begin{array}{l}\text { information post- } \\
\text { ed by a specific } \\
\text { person is adopted }\end{array}$ & $8.6 \%$ \\
\hline & $\begin{array}{l}\text { information post- } \\
\text { ed by a specific } \\
\text { group is adopted }\end{array}$ & $0 \%$ & $\begin{array}{l}\text { information post- } \\
\text { ed by a specific } \\
\text { group is adopted }\end{array}$ & $55.6 \%$ & $\begin{array}{l}\text { information post- } \\
\text { ed by a specific } \\
\text { group is adopted }\end{array}$ & $7.5 \%$ \\
\hline & $\begin{array}{l}\text { all information } \\
\text { from virtual com- } \\
\text { munities is adopt- } \\
\text { ed }\end{array}$ & $0 \%$ & $\begin{array}{l}\text { all information } \\
\text { from virtual com- } \\
\text { munities is adopt- } \\
\text { ed }\end{array}$ & $44.4 \%$ & $\begin{array}{l}\text { all information } \\
\text { from virtual com- } \\
\text { munities is adopt- } \\
\text { ed }\end{array}$ & $1.1 \%$ \\
\hline
\end{tabular}

Table 7 - Model Fit Indices for the Three Groups

\begin{tabular}{|c|c|c|c|c|c|c|c|c|}
\hline & $\chi^{2}$ & d.f. & $\chi^{2} /$ d.f. & $\begin{array}{c}\text { Standardized } \\
\text { RMR }\end{array}$ & RMSEA & NFI & CFI & GFI \\
\hline Model: $\mathbf{1}^{\text {st }}$ Grp & 116.43 & 58 & 2.00 & 0.077 & 0.087 & 0.95 & 0.97 & 0.88 \\
\hline Model: $\mathbf{2}^{\text {nd }}$ Grp & 113.42 & 58 & 1.96 & 0.092 & 0.110 & 0.91 & 0.95 & 0.82 \\
\hline Model: $3^{\text {rd }}$ Grp & 62.56 & 58 & 1.10 & 0.040 & 0.029 & 0.97 & 1.00 & 1.00 \\
\hline
\end{tabular}

When members of this group consider themselves as an integral part of a virtual community and have strong emotional bond with it, they are willing to use information from others' posted messages for decision making. Members in the "information browser" group pay little attention to economic factors, lack sufficient knowledge of cosmetic products to independently make purchase decisions, and have a weak linkage with the virtual community. Hence, these members tend to be willing to accept information, follow others' actions and use them for decision making when they feel themselves to be integral to the virtual communities.

The middle diagram of Figure 3 shows the results of the "information consumer" group. The model revealed that only emotional trust directly increased the members' intention to use information for decision making. A sense of belonging indirectly enhances this since it is an important determinant of emotional trust, as evident from the path coefficient and explained variance and in comparison with the results of the "information browser" group. Accordingly, members who expect to receive guidance from a virtual community for purchase decisions think that feeling integral to the community is critical for making them more likely to use this information for making purchase decisions. The reason for this may arise from the fact that members of the "information consumer" group have little knowledge of cosmetic products, and tend to observe and follow the actions of other people whom they trust.

The bottom diagram of Figure 3 shows the result of the "information provider" group. The 


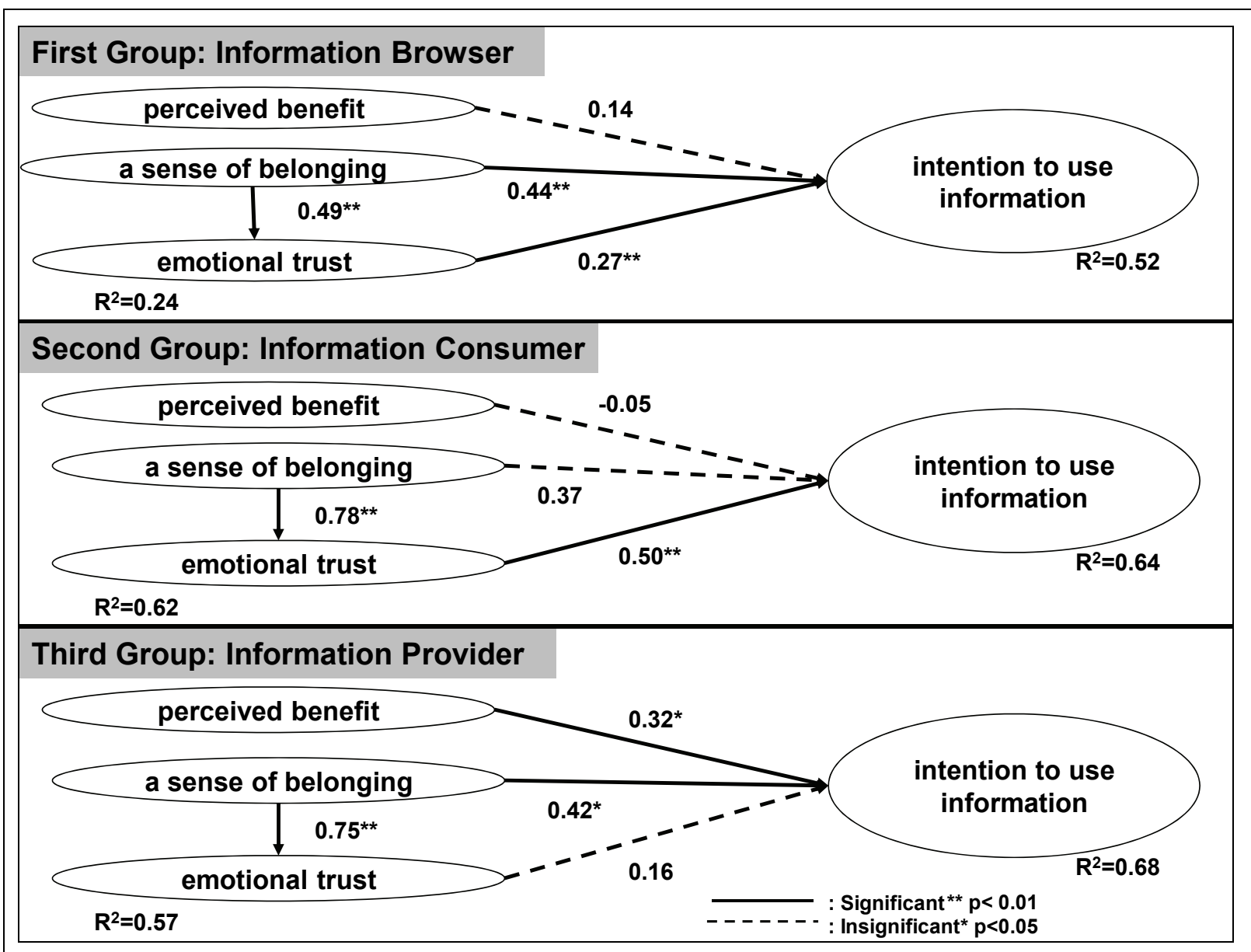

\section{Figure 3 - Moderating Effect: Group by Usage Behavior}

association of emotional trust with the intention to use information for decision making was insignificant. Perceived benefit and a sense of belonging were the main antecedents of the intention to use information for decision making. A sense of belonging highly influences emotional trust, thus explaining the average variance value of $>50 \%$ for emotional trust. "Information providers are primary contributors to the virtual community. They think that the perceived benefit and a sense of belonging are their major considerations to use information as an aid to purchase-related decision making. Emotional trust in virtual communities is irrelevant to purchase-related decision making. Members in the "information provider" group seemingly take into account economic factors (perceived benefit) rather than relational factors (emotional trust). However, social factors (a sense of belonging) remain important in all groups. This finding is accordance with the findings of the study of Preece et al. (2004), which showed that posters think they receive more benefits from virtual communities.

According to the information cascade theory, others have little influence on users who are very knowledgeable about a product (Duan, 2009). They will not simply follow others' actions, unless they think that the information from others' opinions is valuable; they carefully evaluate information quality and usefulness. However, their connections with a specific group within the community are so close that they are willing to follow the actions of the individuals within this specific group.

The relationship of perceived benefit and intention is significant only in the "information provider" group, so $\mathrm{H} 5 \mathrm{a}$ is partially supported. 
The relationship of a sense of belonging and intention is significant in both the "information browser" and "information provider" groups, so $\mathrm{H} 5 \mathrm{~b}$ is partially supported. The relationship of emotional trust and intention is significant in both the "information browser" and "information consumer" groups, so $\mathrm{H} 5 \mathrm{c}$ is partially supported. Accordingly, H5 is partially supported.

\section{Discussion and Implications}

\section{Academic Implications}

This study attempts to determine the influence of a virtual community on members' intentions to use information for decision making by thorough consideration of the effects of an individual's usage behavior. Our results show that all hypotheses are statistically supported, except hypothesis 1 , which indicates the relationship between perceived benefits and the intention to use information for decision making. The analysis of the main effects shows that a sense of belonging and emotional trust are significant antecedents of this intention, which is in accordance with the findings of previous studies, such as those of Komiak and Benbasat (2004) and Lin (2007). However, the insignificant effect of perceived benefits on the intention to use information for decision making differs from the findings of Lope and Galletta (2006).

We found further evidence that more than two types of usage behavior exist for members and that the major contributors to the intention to use information for purchase-related decision making differ in each of these categories. Previous studies have classified users into posters and lurkers based on posting behaviors (Preece et al., 2004 and Ridings et al., 2006). However, the results of this study reveal that lurkers can further be divided into two groups based on how they valuate information from a virtual community. In addition, this study also showed that although posters are the major contributors to a virtual community, they themselves do not appreciate the information posted by others. As a result, we categorized the subjects into three groups: information browsers, information consumers, and information providers.

The "information browsers" group, like onlookers, seldom posts and has little confidence in the information on a virtual community. Although the "information consumers" seldom post, they believe in most of the information from a virtual community. The "information providers" love to share their experience and knowledge with other members, but seldom refer to others' opinions.

A sense of belonging is always critical to the intention to use information for decision making among all these groups. The influences of perceived benefit and emotional trust on intention to use information for decision making vary with the members' behaviors. Preece et al. (2004) indicated that posters' attitudes toward a virtual community are different from those of lurkers. Ridings et al. (2006) also proposed that the willingness to exchange information and social support differs between posters and lurkers.

With regard to the comparison of the three groups, this study presents three interesting findings. First, the perceived benefit from a virtual community is one of the main incentives to motivate information providers. This finding contrasts with other studies in the literature, which indicate that deeply involved members do not concern themselves with the benefits from virtual communities; however, our finding is in accordance with the findings of Preece et al. (2004), which indicate that posters think that they receive more benefit from the virtual community than lurkers. Information providers usually post questions, information, or opinions in the virtual community and can get more responses from other members. The more responses they get, the more opportunities they have to find out valuable information. In comparison with lurkers, members who frequently post could have more information and, hence, more chances to get useful information. In addition, the virtual community provided opportunities to try out free cosmetics samples to particular members based on their degree of involvement and posting history. It was the respon- 
sibility of these members to post messages related to their experience of these trials visà-vis effectiveness, quality, sensation, etc. If members do not do their duty well, their qualification will be rescinded. The purpose of providing free samples for particular members is to improve information quality. When there is more useful information in a virtual community, acceptance and usability will be greatly improved. Hence, if information providers perceive information usefulness, they are more willing to accept and use it.

Second, lurkers were further categorized into "information consumers" and "information browsers." The main difference between these subcategories is sense of belonging in the formation of the intention to use information for decision making. Perceived benefit is insignificantly associated with intention while emotional trust is significantly associated with intention in both groups. Although "information consumers" expect information from a virtual community for purchase-related decision making, they adopt it only when they deeply rely on the community. The determinant of reliance arises from the feeling of being an integral part of the community. On the contrary, among "information browsers," a sense of belonging as well as emotional trust directly affects the formation of the intention to use information for decision making.

Third, the relative importance of the perceived benefit and emotional trust depends on the members' posting behaviors. Besides social factors, "information browsers" and "information consumers" pay significant attention to trust, whereas "information providers" lay emphasis on the role of the perceived benefit.

\section{Managerial Implications}

Our findings lead to two suggestions for the managers of virtual communities. First, the link between posting behavior and external rewards of the real world may be an effective way to induce members to pleasurably share their expert opinions. Our findings reveal that although "information providers" are good at posting messages, they seldom refer to others' opinions as decision aids. "Information providers," the major virtual community posters, are willing to use information for decision making only when they perceive certain virtual community benefits. Virtual communities could try to provide useful information so as to enhance the sense of perceived benefit for information providers. Providing extrinsic rewards related to the business of virtual communities may be a good way. For example, the targeted virtual community provided particular members with trial cosmetics samples. Therefore, the chosen members were willing to suggest products or share experience that they really liked and appreciated. Once the information on the virtual community is rich, accurate, and valuable, many individuals will be attracted to join the community and will be willing to follow the information to buy the related products (such as cosmetics in our study). Vendors whose products are recommended will increasingly receive orders, leading them to continuously support such a virtual community, as it can raise their professional image, reputation, and profits. Vendors, information providers, other members, and virtual communities benefit from this strategy. Accordingly, managers of virtual communities could foster groups of members whose primary duties include posting helpful messages so as to enrich the quantity and quality of the content on the virtual community. This, in turn, could attract more people to participate in the virtual community.

Second, lurkers can be categorized further into two groups: the "information browsers" group, which generally views information simply as a reference, and the "information consumers" group, which generally accepts most virtual community information. The factors that enhance the members' intention to use information for decision making are distinct between these two groups. Information browsers think that both "a sense of belonging" and "emotional trust" are important. The right way to improve information consumers' intention to use information for decision making is to increase their emotional trust in virtual communities. Managers could try to hold online activities that would increase intimacy and coherence among members so as to 
raise members' perception of a sense of belonging. Managers could also pay more attention to increasing members' emotional trust. For lurkers, both senses of belonging and emotional trust are major determinants of using posted messages for purchase-related decision making. Accordingly, managers could profile their silent members and then give different types of members what they care about so as to improve the use of posted messages for purchase-related decision making.

\section{Limitations}

Our study results should be treated with caution due to the limitations of our study, which have been outlined below. First, the data was collected from only one virtual community; hence, the generalizability of findings may be limited. However, since the targeted community of our study is the most popular beauty virtual community in Taiwan, the impact of this limitation could be low. Second, the data was collected through a self-administered web questionnaire; hence, the doubts of selfselection may lead to biases. However, our research design attempted to eliminate duplicate responses by controlling the member accounts. Third, since this study is exploratory in nature, the findings have to be thoroughly based on a solid foundation of theory in the future.

\section{References}

Bagozzi, R.P. (1980). Casual Models in Marketing, John Wiley and Sons: New York.

Balasubramanian, S. and Mahajan, V. (2001). "The Economic Leverage of the Virtual Community," International Journal of Electronic Commerce, 5, pp. 103-138.

Banerjee, A.V. (1992). "A Simple Model of Herd Behavior," Quarterly Journal of Economics, 107(3), pp. 47-63.

Bentler, P.M. (1980). "Multivariate Analysis with Latent Variables: Casual Modeling," Annual Review of Psychology, 31, pp. 419-456.
Bhattacherjee, A. and Sanford, C. (2006). "Influence Processes for Information Technology Acceptance: An Elaboration Likelihood Model," MIS Quarterly, 30(4), pp. 805-825.

Bikhchandani, S., Hirshleifer, D. and Welch, I. (1992). "A Theory of Fads, Fashion, Custom, and Cultural Change as Informational Cascades," Journal of Political Economy, 100(5), pp. 992-1026.

Blau, P.M. (1968). "Interaction: Social Exchange," International Encyclopedia of Social Sciences, 7, pp. 452-458.

Blumler, J. and Katz, E. (1974). The Uses of Mass Communication, Sage Publications: Thousand Oaks, California.

Chan, C., Meng, L., Bhandar, M., Oh, L.B. and Chan, H.C. (2004). "Recognition and Participation in a Virtual Community," 37th Hawaii International Conference on Systems Sciences, Big Island, Hawaii, USA, January 5-8, 2004.

Cheung, C.M.K., Lee, M.K.O. and Rabjohn, N. (2008). "The Impact of Electronic Word-of-Mouth: The Adoption of Online Opinions in Online Customer Communities," Internet Research, 18(3), pp. 229-247.

Duan, W., Gu, B. and Whinston, A.B. (2009). "Information Cascades and Software Adoption on the Internet: An Empirical Investigation," MIS Quarterly, 33(1), pp. 23-48.

Fishbein, M. and Ajzen, I. (1975). Belief, Attitude, Intention and Behavior: An Introduction to theory and research, Addison-Wesley Reading: Massachusetts.

Fornell, C. and Larcker, D.F. (1981). "Evaluating Structural Equation Models with Unobservable Variables and Measurement Error," Journal of Marketing Research, 36(10), pp. 1246-1255.

Hagel, H. and Armstrong, A.G. (1997). Net Gain: Expanding Markets through Vir- 
Motivations for Using Information for Decision making in Virtual Communities / Huang,Farn and Jeng

tual Communities, Harvard Business School Press: Boston, Massachusetts.

Hagerty, B.M.K., Lynch-Sauer, J., Ptusky, K., Bouwsema, M. and Collier, P. (1992). "Sense of Belonging: A Vital Mental Health Concept," Archives of Psychiatric Nursing, 6(3), pp. 172-177.

Hagerty, B.M.K., Lynch-Sauer, J., Ptusky, K., Bouwsema, M. and Collier, P. (1996). "Sense of Belonging and Indicators of Social and Psychological Functioning," Archives of Psychiatric Nursing, 10(4), pp. 235-44.

Hampton, K. and Wellman, B. (2001). "Long Distance Community in the Network Society: Contact and Support beyond Netville," The American Behavioral Scientist, 45(3), pp. 476-495.

Hennig-Thurau, T., Gwinner, K.P., Walsh, G. and Gremler, D.D. (2004). "Electronic Word-of-Mouth via Consumer-Opinion Platforms: What Motivates Consumers to Articulate themselves on the Internet?" Journal of Interactive Marketing, 18(1), pp.38-52.

Hung, K.H. and Li, S.Y. (2007). "The Influence of eWOM on Virtual Consumer Communities: Social Capital, Consumer Learning, and Behavioral Outcomes," Journal of Advertising Research, 47(4), pp. 485-495.

Karakaya, F., Barnes, N.G. (2010). "Impact of Online Reviews of Customer Care Experience on Brand or Company Selection," Journal of Consumer Marketing, 27(5), pp.447-457.

Kim, W.G., Lee, C. and Hiemstra, S.J. (2004). "Effects of an Online Virtual Community on Customer Loyalty and Travel Product Purchases," Tourism Management, 25(2), pp. 343-355.

Kim,. H.W., Gupta, S. and Koh, J. (2011). "Investigating the Intention to Purchase Digital Items in Social Networking Communities: A Customers Value perspective," Information and Management, 48(6), pp. 228-234.
Komiak, S.Y.X. and Benbasat, I. (2004). "Understanding Customer Trust in AgentMediated Electronic Commerce, WebMediated Electronic Commerce, and Traditional Commerce," Information Technology and Management, 5, pp. 181-207.

Komiak, S.Y.X. and Benbasat, I. (2006). "The Effects of Personalization and Familiarity on Trust and Adoption of Recommendation Agents," MIS Quarterly, 30(4), pp. 941-960.

Kramer, R.M. (1999). "Trust and Distrust in Organizations: Emerging Perspectives, Enduring Questions," Annual Review of Psychology, 50, pp. 569-598.

Lee, F.S.L., Vogel, D. and Limayem, M. (2003). "Virtual Community Informatics: A Review and Research Agenda," Journal of Information Technology Theory and Application, 5(1), pp. 4761.

Lessig, V.P. and Park, C.W. (1975). "Promotional Perspectives of Reference Group Influence: Advertising Implication," Journal of Advertising, pp. 41-47.

Liao, S. and Chou, E.Y. (2012). "Intention to Adopt Knowledge through Virtual Communities: Posters vs. Lurkers," Online Information Review, 36(3).

Lin, H.F. (2007). "The Role of Online and Offline Features in Sustaining Virtual Communities: An Empirical Study," Internet Research, 17(2), pp. 119-138.

Lopes, A.B. and Galletta, D.F. (2006). "Consumer Perceptions and Willingness to Pay for Intrinsically Motivated Online Content," Journal of Management Information Systems, 23(2), pp. 203-231.

McKnight, D.H., Choudhury, V. and Kacmar, C. (2002)."Developing and Validating Trust Measures for e-Commerce: An Integrative Typology," Information Systems Research, 13(3), pp. 334359. 
Morgan, R.M. and Hunt, S.D. (1994). "The Commitment-Trust Theory of Relationship Marketing," Journal of Marketing, 58, pp. 20-38.

Pentina, I., Prybutok, V.R. and Zhang, X. (2008). "The Role of Virtual Community as Shopping Reference Group," Journal of Electronic Commerce Research, 9(2), pp. 114-136.

Preece, J., Nonnecke, B. and Andrew, D. (2004). "The Top Five Reasons for Lurking: Improving Community Experiences for Everyone," Computers in Human Behavior, 20(2), pp. 201-223.

Rabjohn, N., Cheung, C.M.K. and Lee, M.K.O. (2008), "Examining the Perceived Credibility of Online Opinions: Information Adoption in the Online Environment," Proceedings of the 41st Hawaii International Conference on Systems Sciences, Big Island, Hawaii, USA, January 7-10, 2004.

Ridings, C. and Gefen, D. (2004). "Virtual Community Attraction: Why People Hang Out Online," Journal of Computer-Mediated Communications, 10(1), Retrieved from http://jcmc.indiana.edu/vol10/issue1/ri dings_gefen.html on October 12, 2009.

Ridings, C., Gefen, D. and Arinze, B. (2006). "Psychological Barriers: Lurker and Poster Motivation and Behavior in Online Community," Communications of the Association for Information Systems, 18, pp. 329-354.

Ridings, C.M., Gefen, D. and Arinzw, B. (2002), "Some Antecedents and Effects of Trust in Virtual Communities," The Journal of Strategic Information Systems, 11(3/4), pp. 271-295.
Roberts, T.L. (1998). "Are Newsgroups Virtual Communities," Proceedings of $\mathrm{CHI}$ 98 Conference on Human Factors in Computing Systems, pp. 360-367.

Smith, D., Menon, S. and Sivakumar, K. (2005), "Online Peer and Editorial Recommendations, Trust, and Choice in Virtual Markets," Journal of Interactive Marketing, 19(3), pp. 15-37.

Sussman, S.W. and Siegl, W.S. (2003). "Information Influences in Organizations: An Integrated Approach to Knowledge Adoption," Information Systems Research, 14(1), pp. 47-65.

Thibaut, J.W. and Kelley, H.H. (1959). The Social Psychology of Groups, John Wiley \& Sons: New York.

Wang, Y. and Fesenmaier, D.R. (2004a). "Modeling Participation in an Online Travel Community," Journal of Travel Research, 42(3), pp. 261.

Wang, Y. and Fesenmaier, D.R. (2004b). 'Toward Understanding Members' General Participation in and Active Contribution to an online Travel Community," Tourism Management, 25, pp. 709-722.

Yovits, M.C. and Foulk, C.R. (1985). "Experiments and Analysis of Information Use and Value in a Decision-Making Context," Journal of the American Society for Information Science, 36(2), pp. 63-81.

Zhou, L., Dai, L. and Zhang, D. (2007). "Online Shopping Acceptance Model A Critical Survey of Consumer Factors in Online Shopping," Journal of Electronic Commerce Research, 8(1), pp. 41-62. 
Privacy and Security Aspects of Social Media: Institutional and Technological Environment / Kshetri

\section{About Authors}

Dr. Li-Ting Huang is Associate Professor in the Department of Information Management at Chang Gung University in Taiwan. Her research interests include e-commerce, internet marketing and inter-organization collaboration. She has published in international journals, such as Cyberpsychology, Behavior, and Social Networking, Computers \& Industrial Engineering, Total Quality Management \& Business Excellence Journal, Management Review, Journal of Information Management, Sun Yat-Sen Management Review, etc.

Dr. Hann-Tarn Jeng is Associate Professor in the Department of Accounting at the $\mathrm{Na}$ tional Central University. His teaching and research interests include business model based key performance indicators, manage- ment simulation and gaming for higher education, and management control systems. He has published in journals such as Quarterly Journal of Business and Economics, and Applied Economics $\circ \mathrm{He}$ is also a consultant to many private enterprises.

Dr. Cheng-Kiang Farn is Distinguished Professor in the Department of Information Management at National Central University in Taiwan. His teaching and research interests focus on electronic business, supply chain management and knowledge management. His major publications have been in the areas of electronic business and management of IS. $\mathrm{He}$ is also a consultant to many government agencies and enterprises. 